\title{
The impact on branded product on consumer purchase intentions
}

\author{
Muhammad Rizwan \\ Lecturer, Department of Management Sciences \\ The Islamia University of Bahawalpur, Pakistan \\ E-mail: rizwan.arshad@iub.edu.pk
}

Mudasser Qayyum

Research scholar, Department of Management Sciences

The Islamia University of Bahawalpur, Pakistan

Waqas Qadeer

Research scholar, Department of Management Sciences

The Islamia University of Bahawalpur, Pakistan

\section{Javed}

Research scholar, Department of Management Sciences

The Islamia University of Bahawalpur, Pakistan

Accepted: July 02, 2014

Doi:10.5296/jpag.v4i3.5849 URL: http://dx.doi.org/10.5296/jpag.v4i3.5849

\begin{abstract}
The objective of this study is to absorb the brand trust, brand satisfaction and brand attachment with ecological cost influence of consumer purchase intention. This study seeks to investigate the effect of aparant product image straight and unforeseen effects of low price, past experience,brand attachment and product awareness on customer purchase intention. Lead the consumer want to buy branded products and attached with brands. The two key factors, brand trust and brand attachment are effective on consumer purchase intention toward branded products. This questionnaire surveys distributed to Levi's jeans user in Pakistan, in 160 questionnare distributed, 158 athentic questionnaire were returned. This result shows,
\end{abstract}


customer in pakistan explain soaring purchase intention to branded product, Levie's jeans. Brand trust and brand attachment have a positive effective on their purchase intention. This outcome show that applicant show a high intention to eacquire environmental gracious wines as well report solid relationship to the atmosphere. The study aim an useful constitutionnel mold and remark positive effective factors for consumers ${ }^{\text {ee }}$ purchase intention towards branded products.

Keywords: Brand trust, Brand satisfaction, Brand attachment, Low price, Purchase intention

\section{Introduction}

Now a dayes world is more mindful regarding culture whenever you make a purchase decision. Purchase intention refers to a plan to purchase an exacting good or service in the future (Business Dictionary.com 2010). The present principled, spiritual, proper and ecological bound the mankind toward feel of it acutely like refusal extra decline is reasonably priced to the world. Ecological dreadful conditions and decline is the major hostile issue now a day mankind. To acquire intention a customer could think ecological issue. Regardless of the real that customer are aware the environmental issues in relation to purchase Intention. Objective has mostly apply able and determination mostly have a positive significant on separate proceedings.

To be relevant any such intention to purchase methods to calculate intentions for customer product and services, manufacturers or dealers must first find out some way to transmit this product information to the latent customers. Fitzsimons and Morwitz (1996) confirmed that measuring intentions influence which brands customer purchase. Purchase intention may classify as one of the mechanism of customer cognitive behavior on how particular intended to purchase a particular product. Laroche Zhou (1996) argue that variables such as consumer deliberation in purchasing a brand and hope to purchase a product may use to determine customer purchase intention. These deliberation factors can consist of the customer's involved, attending, information and assessment as a part of the whole procedure in influential purchase intent.

Customers current regularly build procure intention base on how goods gratify their requirements and wants while minimize insignificant affect on the usual environment and Purchase intention have commonly in text or journalism like forecaster of following purchasing.Purchase intention is a measure of readiness to buy a product and has also been set as the probability that a consumer will buy a product or services. Investigation of consumer perceptions and investigation processes is critically important seeing as it can help marketers to seeing as more willing how influences consumer purchase intention. Purchase intention may difficult contain a mixture of wishes and wants affect by factor like value system,social and ecological norms. Purchasing performance may affected by interior and exterior factor. Purchase intention comes into deliberations when a customer is maybe attempt to buy some product or service.

Purchase intention taking original goods aspect in relation and spite the reason is that, 
evaluation to purchase a goods get intention but more prominently represents a brand choice. Previous research have exposed, almost $1 / 3$ of customer could intentionally buy produts and increasing aware of single and company impact on nature to behave and carry put modifications in manufacture and market place. These outcomes recommend that, the perform of measure intention may influence customer consciences almost the latent buy a product and alter their subsequence purchase actions.

In this way which factors persuade consumer assessment of a purchase intention becomes the focus of the inspection. Utilization of the product is a purchase intention that fulfilled one's simple look. The group find that almost $1 / 3$ of customer could intentionally buy fake products given the right price and value and twenty nine per cent saw no harm in product as long as the products do not put the purchaser at risk and first time purchase of the product is may harm or not. Whereas this might limited the extent the findings tender benefits for purchase intention houses that specialise in high involvement rather than less contribution products.Question is that How clients build up connection or intrection with purchase intention?

Brand attachment makes interface and specify brands strongly show an results in expand, how repeatedly goods was purchase in previous years and shall be purchase in next time. Brand satisfaction is integrated in faith is add on goods to testifies normal and influensive outcomes. Believe on the brands is effect base, referels to a contact which is outcomes of community interact related with brands. Past experience with simple product can critical in shaping the goods particular observation that could leads next time buy intent in turn customers previous experience effecton purchase or usage of simple product.

Low price is a main determinant inspiring demand for fake products. Consumers desire to buy original brands but only some of them can manage to pay. The premium priced original brands provide chance to less priced fake to meet the requirements of those who cannot afford original brands. Customers product knowledge have well-known whereas feature that effective all phase in the decision critaria.Customers with a variety of level of goods information vary in their perception of a products.Customers with superior level of goods information has superior develop and moreover typicall schema with well formulate decision critaria.

\section{Literature Review}

\section{Purchase Intention}

The main fundamental aspect of consumer behaviour is their purchase intention which in literature is defined as the situation in which a customer is agreeable to make a transaction with the retailer. According to Dodds, Monroe and Grewal (1991) purchase intention comes into deliberation when a customer is most likely attempting to purchase some product or service. For marketers purchase intention is of vast meaning as their forecasted consumer behaviour is highly dependent on this purchase intention of the customers. Predicting consumer behaviour is one of the most deadly tasks for any business as it keeps on altering under the influences of unknown and doubtful factors; therefore leading to a purchase 
intention which is dardly to measure under different conditions (Rizwan et al., 2013).

Purchase intention may amount the chances of a buyer to purchase a producer, larger the buyer intent is, the larger a buyer's intent to purchase a goods (Dodds et al. 1991; Schiffman and Kanuk, 2000). Buyer intent specifies, buyers will stay up with theirs know-how, first selection and external vicinity to collect information, and make buying choice by assessing substitutes (Zeithaml, 1988; Dodds et al. 1991; Schiffman and Kanuk, 2000; Yang, 2009; Rizwan et al., 2013).

This revision focus on buyer intent not behavior,intent have mostly implications and will often have a good influence individual action (Ajzen and Driver, 1992; Pierre et al., 2005; Schlosser et al., 2006). Several studies claimed that purchase intention is a function of monetary deliberations too, and not only of behavior. furthermore, apparent affordability is an economic variable that can influence behavioral intention (perceived economic control). Hence, the purchase of that goods is prompted by the professed ability to afford a product, no matter whether the buyer becomes attentive of the product as pricey or low-priced. The present study projected investigation consequences self-assessment goods information, goods involved, and buyer's thinked good image of fake goods, along with the interaction among these variables on buyer"s purchase intention.

\section{Brand Satisfaction}

Consumer satisfy and discontent are the customer judgment whereas a firm succeed or letdown in meet expectation (Oliver 1980). Met potential outcomes in consumer satisfaction un met expectation outcomes in consumers frustration. In his other writings, Oliver (1997) define satisfactory summary of mental state results when the feeling immediate unconfirmed expectation is attached with prior feeling almost customer practice. In simple, satisfactions have conceptualize in term of whether the goods or services meet customer requirements and expectation (Zeithaml \& Bitner 2000.Focusing on the seller industry, satisfaction with brand or brand satisfactions is definite as a cognitive estimation of whether or not the swap relation with brand is satisfying (Esch et al. 2006).

H1. There is a significant relationship between Brand satisfaction and consumer purchase intention.

\section{Brand attachment}

Brand attachment towards merely if a brand results is a satisfiy consumer and is trust from customer then they will be connections that may visible (Berry, 2000). Believe on the brands is influence base,who referells to attached which is the outcome of public interface connecte with brand (Esch et al., 2006). Hense mold satisfactory for branded products added in faith on the branded things to testifted coherent and influence outcomes. While interaction are relations in excess of time. 


\section{Macrothink}

Hence one extra build have integrated, indicate this inter dependence attach to the branded goods. Simply if brand result is a satisfy consumer and is reliable by the consumer shall connected that can be discernible. Second is that the attached toward the brand make interface and specify the brand strongly show a results in advanced that how frequently goods was buy in the previous and will be buy in the upcoming. Branded product play good job in company linked to military since brand which are powerfully boost the rate of consumer believe of the purchases that is imperceptible.

Earlier suggest that past in 1990s consumer constancy is noticeable as a key idea alongside in company with many others that contain of promise, fulfilment, appreciation, belief and the relation with most important to brand. Belief of the consumer and liking with a merchant mediate the collision of belief in brand and pleasure on client intention to purchase. Sirdesh mukh et al. (2002) stated belief of the consumer as a imperative and essential build in initial consumer interaction stronger and attain sustainable shares in the markets. A small number of segment allied to customers are attracted in shop brand anywhere consumers that are pleased. Delgado-Ballester and Munuera-Aleman (2005) stated belief linked from earlier period practice become the part for present obtain and term the customer as faithful which additional intact the product fairness.

\section{Brand Trust}

In matches brand belief is a well researched market buildup. Delgado-Ballester, Munuera-Aleman, and Yague-Guillen (2003) defined brand belief as ,the certain expectation of the brand consistency and intenti in situation entail risk toward customers (p. 37). Such as brand belief is one reasonable result of brand awareness and brand like. Therefore worldwide brands familiarities and world wide brand are essential precondition for universal brand belief. It seem not likely that world wide brand belief would be constract if customer were unknownwith or not liked the world wide brand.

Researcher has connected brand belief with brand satisfaction greater market share and promote efficiency brand justness. Recent Romaniuk and Bogomolova (2005) have calculated world wide brand various in term of trust. They sample consumer live in the UK and Australia and embarrassed for product volume influence in the belief score of one hundred ten local brand in market. They find small variation in brand belief scores when handling fo rmarket shares.Belief is addition like a sanitation issue in that all brand has accurate level of trust to be aggressive in the markets. This findings make logic give the markets similarity of the UK and Australia

H2. There is significant relationship between Brand trust and Brand attachment on consumer purchase intention.

H3. There is significant relationship between Brand satisfaction and Brand attachment on consumer purchase intention. 


\section{Product knowledge}

Customers product information have familiar like feature that influence all phase in the conclusion progression (Bettman and Park, 1980). Customers with different levels of contrived goods in sequence differ in their perception of a products. Customers with greater level of product information have good developed and more multifaceted schema with well formulated conclusion criterion (Marks and Olson, 1981). While they procedure knowledge, less cognitive effort is mandatory and applicable information structure can be activate by design, and they are capable to procedure more information.

Previous study argue that, given superior- suburban and more composite schema customers with better levels of product knowledge have better cognitive capacity to evaluate comparative alternatives. This idea agree with Kempf and Smith (1998), who advise, that customers with big levels of product knowledge are more suggestive and knowledge able than those who have small levels of product information. Therefore, the big the level of product information a customers possess the less possibility he/she will produce estimate bias with the result that knowledge able consumers are likely to value that CBPs are low grade BPs.Self-perceived knowledge operates as a direct positive influencer of purchase intentions for unusual branded long-lasting products (Berger et al., 1994).

In the background consumers with higher level of product information are able to assess branded product more accurately and become low favorable and agreeable to BPs.Thus, they should give less support and to the grade of branded product and show low preference for brande products nature apparent information operate as a straight optimistic influence of purchase intention for inventive branded sturdy products (Berger et al., 1994).

Accordingly, this research attempt to test the following hypotheses.

H4. There is a significant relationship between product knowledge and consumer purchase intention.

\section{Low Price}

Low price is a very important causal issue affect demand for imitated goods (Dodge et al. 1996; Albers Miller, 1999; Prendergast et al. 2002; Harvey and Walls, 2003). Customer wish to purchase new products but just few of them can acquire them. Those who cannot buy innovative brands, the best priced real brands give a opportunity to low priced counterfeits to complete their demand.

Low price has been generate to object require for unreliabe products. By the purchase side and low price, customer identify non-deceptive counterfeits (Prendergast et al. 2002). In adding up, more or less buyers recomended to accept comfortable style of living but are not financially good sufficient to purchase real brands and are led with the option of imitated goods.Likely, price aware buyers purposely purchase imitated goods as these are 
cost-efficient (Haque et al. 2009; Gino, 2010). The relationship between brand loyalty and price feeling has been a topic of interest to marketers for many years. One can wind up that consumer thought to make a decision product brand is mostly based on price. Researchers have examined whether and how reliability affects the price that customer are agree to pay for a brand.

Recent researches on brand were conduct on construct strong brands, brand image on estimates of internal price values, price effects on brand porch quality valuations or price consciousness in brand conservatory, planned bundling of price. Deceptive counterfeits' low price has been witnessed to excite demand for nondeceptive counterfeits (Staake and Fleisch, 2008). Low price is an important determinant stimulating demand for branded products. On the basis of the existing literature we postulate that low price affects young customer attitude towards non misleading counterfeit products positively But at the same time we recommend that low price for non deceptive counterfeits product positively influence purchase intentions of young customer. Consumers prefer counterfeits over real brands specially when counterfeits are clearly available at lower prices (Bloch et al., 1993; Gentry, 2006; Ergin, 2010).

H5. There is a significant relationship between Low price and consumer purchase intention.

\section{Past experiences}

Based on the supposition that consumer behavior is the outcome of learning (Bentlar and Speckart, 1979), there is an argument among the researchers that consumer ${ }^{\text {ee }}$ s previous behavior can offered better predictions of behavioral intentions.Delgado-Ballester and Munuera-Aleman (2005) build-up that the believe developed through past experience becomes a crucial part of existing purchase and name the consumer as loyal furthermore serves as brand equity in future.

A lot of researchers have argue that contemplation of customer previous behaviours can provide good predictions of behavioural intention (Conner and Armitage, 1998) based on the postulation that consumers ${ }^{\text {ee }}$ behaviors outcome from knowledge With admiration to do research on purchasing behavior, consumers earlier period experience with immature products could be decisive in forming the product-exact perception that would lead to potential purchase intention in turn consumers earlier period experiences manipulate their purchases or use of products.

Recently, Swami et al. (2009) in a survey of 287 men and women in London found that earlier experience was significant and certainly predicted enthusiasm to purchase products.in their study on intention to buy fake versus genuine things found that consumer prefered original items over fake apart from their products experience however, once customer tried fake and price information was provided, the preference for the valid article diminished and respondents showed a stronger intention to buy products. 
H6. There is a Positive relationship between Past experience and consumer purchase intention.

\section{Research Methodology}

The recent research is descriptive research.Descriptive research is explained as describing somewhat, littlebit factor any specific conditions. Descriptive researche are those researche who explained the existing situations replacement of interpret and making result (creswell 1994). The major aim of the descriptive research is confirmation of the build up hypothesis that replicate the current conditions. These type of researches provide information about the present scenario.

\section{Sample/ data}

In order to gather the data for understanding the situation about the Purchase intention ,a sample of 160 respondents will ask to contribute in a self-adminsterd questionnaire and in 160 questionnare 158 were returned.Present study utilize a no chance sampling method that is expediency sample. Expediency sampling is a sampling method that contain and collect the relevant information from the sample or the unit of study that are conveniently available.Convenience sampling is in general used for gathering a huge number of completed surveys speedily and with economy(Lym et al.2010).

We select these sample members from various places of Bahawalpur. Four key clusters will target to collect the sample statistics like working professionals, the islamia university of Bahawalpur, students etc.

\section{Instrument and measure}

The survey tool of the current study address two major purpose.First is to analyze the relationship of different variables of purchase intention. Second, to collect information about different quality of the respondents that can be worn to recognize the variations in different categories.

The survey mechanism obtain two section. It include different personal demographic variables. This section will contain the respondent's information about gender, age, income, education and status.

The latent variables that are essential in the present study includes purchase intention,brand satisfaction, product knowledge, past experience, brand trust, low price and brand attachment. This section of the study is industrial based on the previous literature and questionnaire.

The scales of the study were adopted from the past literature and published studies. The first variable was purchase intention has one items dependent variable and that scales were taken from (Esch et al., 2006). The second variable brand satisfaction having four items and these scales were taken from(Rizzo et al. 1970) and(Zboja and Voorhess) (2006) .

The third variable was product knowledge contain five items and these scales were taken from(Laroche et al.,). Next variable was brand trust obtain four items and these scales were taken from Matzler it al, (2008). Chanduhuri and Holbrook,(2001) .Other variable was 
brand attachment support having five items and these scales were taken from(Lacoeuilhe, 2000). Next variable was low price having five items and these scales were taken from (Chuchinprakarnm, 2003; Chaudhry et al. 2009). Other variable was past experience having six items and these scales were taken from (Wang et al., 2005; Tom et al., 1998).

Table1: scales of the study:

\begin{tabular}{|c|c|c|c|}
\hline $\begin{array}{l}\mathbf{S r} \\
\#\end{array}$ & Variable & Items & Reference \\
\hline $\mathbf{1}$ & $\begin{array}{l}\text { Purchase } \\
\text { intention }\end{array}$ & $\begin{array}{l}\text { 1.I would intend to buy counterfeit products. } \\
\text { 2.My willingness to buy counterfeit } \\
\text { products is high. } \\
\text { 3.I am likely to purchase any counterfeit } \\
\text { product. } \\
\text { 4.I have a high intention to buy counterfeit } \\
\text { product. }\end{array}$ & (Esch et al., 2006). \\
\hline 2 & $\begin{array}{l}\text { Brand } \\
\text { satisfaction }\end{array}$ & $\begin{array}{l}\text { 1.overall I am satisfied with specific } \\
\text { experience with the brand. } \\
\text { 2. I am satisfied with my decision to } \\
\text { purchase from this brand. }\end{array}$ & $\begin{array}{l}\text { (Rizzo et al. 1970) } \\
\text { and(Zboja and } \\
\text { Voorhess) (2006) }\end{array}$ \\
\hline 3 & $\begin{array}{l}\text { Product } \\
\text { knowledge }\end{array}$ & $\begin{array}{l}\text { 1. The material used in counterfeit products } \\
\text { is good in quality. } \\
\text { 2.Counterfeit products are practical in } \\
\text { performance as original. } \\
\text { 3.Counterfeit products are more user } \\
\text { friendly. } \\
\text { 4.Counterfeit products are secure in usage. } \\
\text { 5.I am fully confident about counterfeit } \\
\text { products as original. }\end{array}$ & (Laroche et al.,). \\
\hline 4 & Brand trust & $\begin{array}{l}\text { 1. I trust on this brand. } \\
\text { 2. I rely on this brand. } \\
\text { 3. This is an honest brand. } \\
\text { 4. This brand meets my expectations. }\end{array}$ & $\begin{array}{l}\text { Matzler it al, } \\
\text { (2008). Chanduhuri } \\
\text { and } \\
\text { Holbrook,(2001). }\end{array}$ \\
\hline
\end{tabular}




\begin{tabular}{|c|c|c|c|}
\hline & & 5. This brand is safe. & \\
\hline 5 & $\begin{array}{l}\text { Brand } \\
\text { attachment }\end{array}$ & $\begin{array}{l}\text { 1. I have a lot of affection for brand } X \text {. } \\
\text { 2. Buying brand } X \text { gives me a lot of joy and } \\
\text { pleasure. } \\
\text { 3. I feel a certain comfort when buying } \\
\text { products from brand } X \text {. } \\
\text { 4. I am very linked to brand X. } \\
\text { 5. I feel attracted to brand X. }\end{array}$ & (Lacoeuilhe, 2000). \\
\hline 6 & Low price & $\begin{array}{l}\text { 1. I usually purchase the least } \\
\text { expensive counterfeit mobiles. } \\
\text { 2. I often find myself checking prices. } \\
\text { 3. I am always attracted towards low } \\
\text { price mobile phones. } \\
\text { 4. The low price of counterfeit mobiles } \\
\text { is appealing to me. } \\
\text { 5.I buy counterfeit mobiles because } \\
\text { the prices of genuine } \\
\text { brands are unfair. }\end{array}$ & $\begin{array}{l}\text { (Chuchinprakarnm, } \\
\text { 2003; Chaudhry et } \\
\text { al. 2009). }\end{array}$ \\
\hline 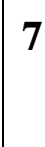 & Past experience & $\begin{array}{l}\text { 1.Counterfeit products have the style, I like. } \\
\text { 2.Counterfeit products was precious for me. }\end{array}$ & $\begin{array}{l}\text { (Wang et al., 2005; } \\
\text { Tom et al., 1998). }\end{array}$ \\
\hline
\end{tabular}

\section{Procedure}

The questionnaire was spread among 160 respondent in Bahawalpur. These respondent are selected based on the criteria above mentioned. Before giving the questionnaire, the purpose of study and questions were explained to the respondents so they can easily fill the questionnaire will related responses. A total of 160 questionnaire were selected. After collecting the 158 questionnaires, these questionnaires were implicit and entered into spss sheet for further analysis.

\section{Reliability analysis}

Over all cronbach alpha of purchase intention questionnare items were 0.942 that is more than satisfactory and recomended value 0.50 by nannally (1970) and by moss et al. (1998). This show that all the 32 items were consistent and athentic to evaluate the opinion of consumer towards purchase intention. 
Table 2:

Reliability of measuring instrument

\begin{tabular}{|l|l|l|}
\hline Scales & Items & Cronbach alpha \\
\hline Purchase Intention & 4 & 0.880 \\
Product Knowledge & 5 & 0.817 \\
Past Experience & 6 & 0.826 \\
Brand Satisfaction & 2 & 0.796 \\
Low Price & 5 & 0.804 \\
Brand Trust & 5 & 0.812 \\
Brand Attachment & 5 & 0.787 \\
\hline
\end{tabular}

\section{Table 3:}

\section{Findings}

\section{Profile of the respondent}

Personal and demographic information such as gender, age, income, education and company are presented in the following table.

\begin{tabular}{|l|l|l|l|}
\hline Variables & Category & Frequency & Percentage \\
\hline Gender & Male & 126 & 79.7 \\
Total & Female & 158 & 20.3 \\
Age & $15-20$ years & 37 & 100.0 \\
\hline 20-25 years & 99 & 23.4 \\
Total & $15-30$ years & 16 & 62.7 \\
$30-35$ years & 3 & 10.1 \\
$35-40$ years & 1 & 1.9 \\
Above 40 years & 2 & 1.3 \\
\hline
\end{tabular}




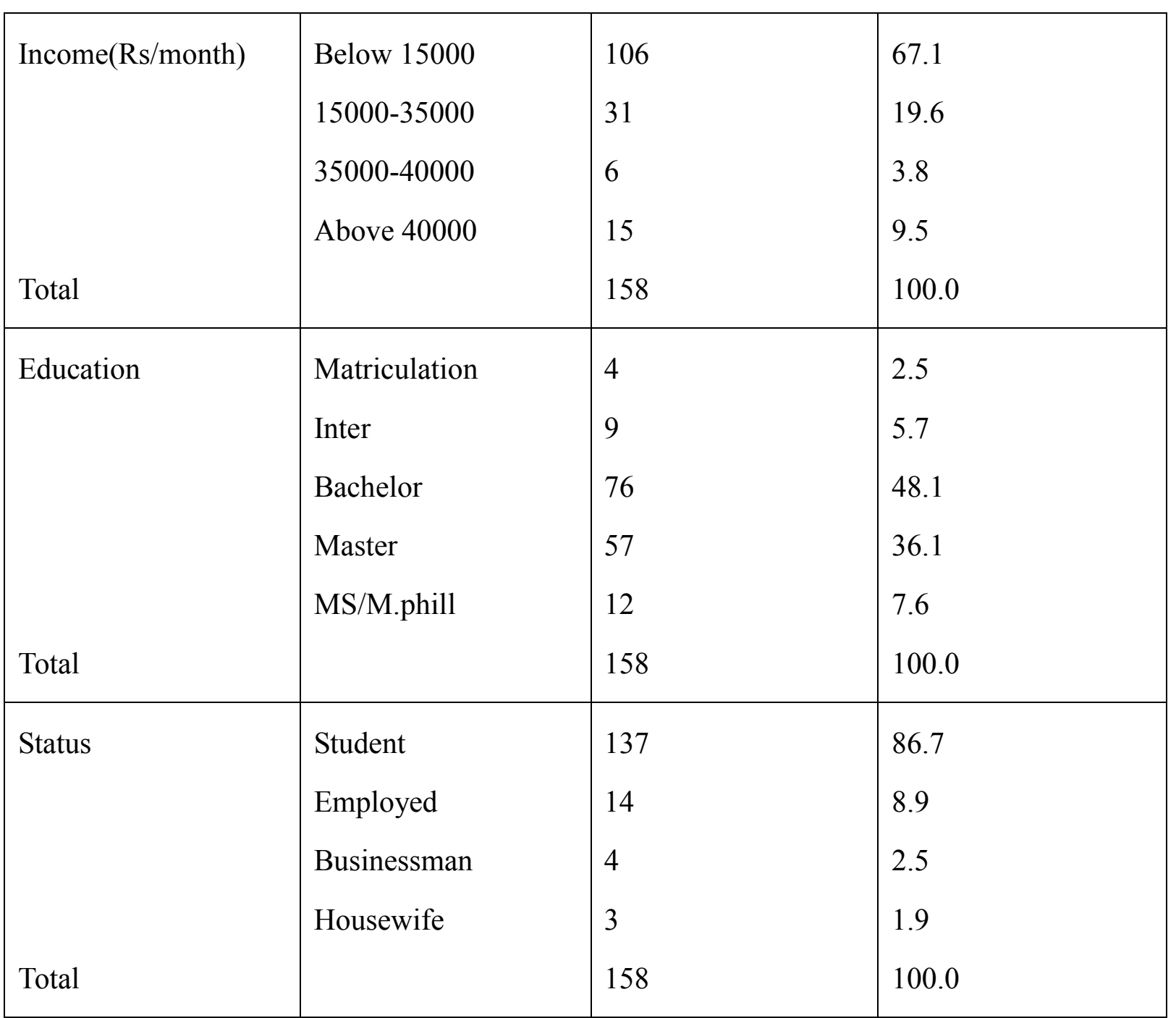

\section{Hypothesis testing}

\section{Purchase intention and brand satisfaction}

According to the results of the study, the variable has significant positive relationship with $(\beta=-.569)$, and significance value $(\mathrm{p}<.001)$ that means purchase intention to brand satisfaction contribute $57 \%$ to purchase intention. Results of current accept the H1.The regression results of the study confirm the significant relationship between brand satisfaction and purchase intention.

\section{Brand Satisfaction,Brand Trust and Brand Attachment}

According to the results of the study, the variable Brand trust has significant positive relationship with $(\beta=-.695)$, and significance value $(p<.001)$ and Brand Satisfaction insignificance to brand attachment.Brand trust $69 \%$ contribute to brand attachment while Brand satisfaction value $(\mathrm{p}>.001)$.

\section{Brand Attachment and Purchase Intention}

The regression analysis results shows that Brand attachment has a positive relationship with 
purchase intention with a $(\beta=0.381)$ and $(p<0.001)$. The results accept the hypothesis. So it validate this hypothesis that means brand attachment to purchase intention contribute $38 \%$ to brand attachment .

\section{Low Price and Purchase Intention}

Low price has a insignificant relationship with purchase intention.the analysis shows that $(\beta=-.091)$ and $(p>0.001)$. Result of current reject.

\section{Past Experience and Purchase Intention}

The regression analysis express that past experience has negative relationship purchase intention with $(\beta=.398)$ and $(\mathrm{p}<0.001)$ so present result validate the hypothesis that means $39 \%$ contribute past experience to purchase intention.so result is accepted.

\section{Product knowledge and Purchase Intention}

According to the results of the study,the variable has insignificant relationship with $(\beta=-.070)$, and significance value $(p>.001)$ that means purchase intention to product knowledge participate only $7 \%$ to purchase intention. So result is rejected.

\section{Table 4:}

Regression Results

\begin{tabular}{|c|c|c|c|c|c|c|}
\hline Hypothesis & Model variables & $\begin{array}{l}\text { Estima } \\
\text { ted }\end{array}$ & S.E & C.R & $\mathrm{P}$ & Results \\
\hline $\mathrm{HI}$ & $\begin{array}{l}\text { Brand satisfaction } \\
\text { purchase intention }\end{array}$ & .569 & $\begin{array}{l}.06 \\
7\end{array}$ & 8.638 & 0.000 & Supported \\
\hline $\mathrm{H} 2$ & $\begin{array}{l}\text { brand } \overrightarrow{\text { satisfaction }} \\
\text { brand attachment }\end{array}$ & .074 & $\begin{array}{l}.06 \\
4\end{array}$ & .978 & 0.330 & $\begin{array}{l}\text { Not } \\
\text { Supported }\end{array}$ \\
\hline $\mathrm{H} 3$ & $\begin{array}{l}\text { brand } \\
\text { brand attachment }\end{array}$ & .695 & $\begin{array}{l}.07 \\
7\end{array}$ & 9.177 & 0.000 & Supported \\
\hline $\mathrm{H} 4$ & $\begin{array}{l}\text { brand } \quad \longrightarrow \text { attachment } \\
\text { purchase intention }\end{array}$ & .381 & $\begin{array}{l}.08 \\
5\end{array}$ & 5.387 & 0.000 & Supported \\
\hline H5 & $\begin{array}{l}\text { Low price } \\
\text { intention }\end{array}$ & -0.091 & $\begin{array}{l}.08 \\
1\end{array}$ & -1.284 & 0.201 & $\begin{array}{l}\text { Not } \\
\text { Supported }\end{array}$ \\
\hline
\end{tabular}




\begin{tabular}{|l|l|l|l|l|l|l|}
\hline H6 & $\begin{array}{l}\text { Past } \\
\text { purchase intention } \\
\text { Prodtet experience } \\
\text { purchase intention }\end{array}$ & .398 & .110 & 4.380 & 0.000 & Supported \\
\hline H7 & .070 & $\begin{array}{l}.09 \\
3\end{array}$ & .846 & 0.399 & $\begin{array}{l}\text { Not } \\
\text { Supported }\end{array}$ \\
\hline
\end{tabular}

\section{Discussion}

One of the key contributions of this model was to provide a superior understanding of how purchase intention affects several variables. The study model posited that purchase intention comes from Brand satisfaction, Brand trust, Brand attachment, Low price, Past experience and Product knowledge. The outcomes suggest that all of these factors influence purchase intention to differing degrees. In most cases,support was found for many, all of the straight effects. The consequences obtained from analysis allow us to verify the build up hypotheses and to undastand the relationship between various variables of acceptance model. The inquiry of this study show that purchase purpose of consumers is positive assenting like prevailing relationship is experimental with brand satisfaction, brand trust, brand attachment, low price, product knowledge, and past experience i.e., the independent variables. Complete analysis shows that the variables which are autonomous in nature influences purchasing intention.

On the other hand the first autonomous variable brand satisfaction show a significant relationship with purchase intention. Whereas the next independent variable brand trust shows a significant relationship with dependent variable. Third variable Brand trust and brand satisfaction show a significant relation with brand attachment. Low price, product knowledge, past experience is also positive relationship with purchase intention. Brand satisfaction $57 \%$ difference in the reliant patchy acquires intention. Brand satisfaction $57 \%$ distinction in the dependent variable i.e. Brand attachment. Brand trust $74 \%$ variation in the dependent variable i.e. Brand attachment. Whole analysis shows that the variables which are autonomous in environment influence purchase intention of consumers and gives a momentous result as $\mathrm{p}<0.01$, and stander error is less than one $(<1)$. The collision of nature on acquire purpose was examine under the class of observation, which is created by Brand values.

Moreover, brand satisfaction and brand trust is also key criterion for the customers to purchase intention.Brand trust and brand satisfaction played important role for consumer purchase intention.Product knowledge and past experience is also significant role in purchase decision. The use experience of the brand has a major influence on purchase Intention. Aaker (1991) expected that later than brand extensions have been passed out by firm, well organized advertising is applicable for both real (original) products and extensive products. When extended products and original products brand extensions can almost certainly hold superior market share and higher advertisement efficiency than other brands. 
Various studies originate that low price is an important determinant inspiring demand for forged products (Dodge et al., 1996; Albers_Miller, 1999, Prendergast et al., 2002; Harvey and Walls, 2003). Customers with greater levels of produce information have better-developed and more intricate schema with well formulate conclusion criteria (Marks and Olson, 1981). While they procedure in sequence, less cognitive attempt is obligatory and pertinent knowledge well-organized can be activated routinely and they are capable to process extra knowledge (Alba and Hutchinson, 1987).

Furthermore this study can also be added undertake on the source of social differences. The limitation of this learning and potential study direction serve up as a ultimate note for this investigation.

\section{Limitations and further research}

Researchers may expand the capacity of comprehensive products or brands for future.

The dominant effects under the variables or scenarios can be studied, which may make the model more useful and common. The data compilation method must too be again redesigne by enchanting chance statistics to boost up its request. For more studies it is optional to use brand satisfaction and brand trust as a mediating or moderate variable.

The testing method by this research are for the indication of firms when setting up brand strategy though there are many other marketing factors may persuade on the success of brand, such as qualified areas, markets, rivalry from other brands, stress and efforts made by firms, etc. The above mentioned factors will perhaps determine the success or not of brand strategy, which can be the research variables for future research.

The data composed contain of sweeping outcome owing to restraint of figures which is non accidental. Purchase intention outcome are momentous and related with journalism lower omission. Model is also superior and athletic of variables. As of the above written outcome it is accomplished that branded product purchase intention are precious by the product satisfaction \& their brand trust toward the brand.

\section{References}

Aaker, A.D., Kumar, V., \& Day, G. (1995). Marketing research. Wiley, New York, NY.

Berry, L.L., 2000. Cultivating service brand equity. J.Acad. Mark. Sci., 28(1): 128-137.

Bloch, P.H., Bush, R.F. and Campbell, L. (1993), "Consumer ,accomplices" in product counterfeiting”, Journal of Consumer Marketing, Vol. 10, pp. 27-36.

Bentler P and Speckart, G. (1979), "Models of attitude-behavior relations", Psychological Review, Vol. 86 No. 5, pp. 452-64.

Berger, I.E., Ratchford, B.T. and Haines, G.H. Jr (1994), "Subjective product knowledge as a moderator of the relationship between attitudes and purchase intentions for a durable product", Journal of Economic Psychology, Vol. 15 No. 2, June, pp. 301-14. 
Bettman, J.A. and Park, C.W. (1980), "Effects of prior knowledge and experience and phase of the choice process on consumer decision-making processes: a protocol analysis", Journal of Consumer Research, Vol. 7 No. 3, December, pp. 234-48.

Blair, M.E. and Innis, D.E. (1996), "The effects of product knowledge on the evaluation of warranted brands", Psychology and Marketing, Vol. 13 No. 5, pp. 445-56.

Chatterjee, S., and A. Chaudhuri. 2005. „Are Trusted Brands Important? ${ }^{\text {ee Marketing }}$ Management Journal 15 (1).

Chaudhry, P. E., Zimmerman, A., Peters, J. R., \& Cordell, V. V. (2009). Preserving intellectual property rights: managerial insight into the escalating counterfeit market quandary. Business Horizons, 52(1), 57-66.

Chaudhry, P.E. and Walsh, M.G. (1996), "An assessment of the impact of counterfeiting in international markets: the paradox persists", Columbia Journal of World Business, Vol. 31 No. 3,pp.34-48.

Chuchinprakarn, S. (2003). Consumption of counterfeit goods in Thailand: who are the patrons? European Advances in Consumer Research, 6, 48-53.

Dodds, B.K., Monroe, K.B. and Grewal, D. (1991), "Effect of price, brands, and store information on buyersee product evaluation", Journal of Marketing Research, Vol. 28, August, pp. 307-19.

Dodge, H.R., Edwards, E.A. and Fullerton, S. (1996), "Consumer transgressions in the marketplace: consumerse perspectives”, Psychology and Marketing, Vol. 13 No. 8, pp. 821-35. Delgado-Ballester, E. and J. Munuera-Aleman, 2005.Does brand trust matter to brand equity? J. Prod. Brand Manage., 14(3): 187-196.

Delgado-Ballester, E., J. L. Munera-Alemain, and M. Yague-Gullien. 2003.,Development and Validation of a Brand Trust Scale. "e International Journal of Market Research 45 (1): 35-53.

Esch, F. R., Langner, T., Schmitt, B. H. and Geus, P. (2006), “Are brands forever? How brand knowledge and relationships affect current and future purchases", Journal of Product and Brand Management, $\quad 15, \quad 2, \quad 98-105$. Fitzsimons, Gavan J. and Vicki G. Morwitz (1996), "The Effect of Measuring Intent on Brand Level Purchase Behavior,” Journal of Consumer Research, 23 (June), 1-11.

Gistri, G., Simona, R., Stefano, P., Veronica, G., \& Silvia, G. (2009). Consumption practices of counterfeit luxury goods in the Italian context. Brand Management, 16 (March), 364-374.

Harvey, P. J., \& Walls, W. D. (2003). Laboratory markets in counterfeit goods: Hong Kong versus Las Vegas. Applied Economics Letters, 10 (November), 883_887. Haque, A., Khatibi, A., \& Rahman, S. (2009). Factors influencing buying behavior of piracy products and its impact to Malaysian market. International Review of Business Research Papers, 5 (March), 383_401.

Rizwan, M., Imran, M., Qayyum, A., Yousaf, M., Qaiser, S., Afzal, S. and Fatima, N. (2013) Consumer's purchase intention towards Counterfeit Mobile Phones, IOSR Journal of 
Business and Management, Vol. 1 (special issue), 36-43

D.S. and Smith, R.E. (1998), "Consumer processing of product trial and the influence of prior advertising: a structural modelling approach”, Journal of Marketing Research, Vol.35 No. 3, August, pp.

325-38.

Laroche, M., Kim, C. and Zhou, L. (1996) 'Brand familiarity and confidence as determinants of purchase intention: an empirical test in a multiple brand context', Journal of Business Research, $37(2)$,

115-120. Lau, G., and S. Lee. 1999. „Consumers"e Trust in a Brand and the Link to Brand Loyalty. Journal of Market FocusedManagement $4 \quad$ (4): 341-70. Marks, L.J. and Olson, J.C. (1981), "Toward a cognitive structure conceptualization of product familiarity", in Monroe, K. and Arbor, A. (Eds), Advances in Consumer Research, Vol. 8, Association for Consumer Research, MI, pp. 145-50. Martenson, R., 2007. Corporate brand image, satisfaction, and store loyalty. Inter. J. Retail Distr. Manage., 35(7):

544-555. Moss, S., Prosser, H., Costello, H. (1998). Reliability and validity of the PAS-ADD Checklist for detecting psychiatric disorders in adults with intellectual disability. Journal of Intellectual . Nunnally, J.C. (1978), Psychometric Theory, 2nd ed., McGraw Hill, New York, NY.

Oliver, R.L. (1980), "A Cognitive Model of the Antecedents and Consequences of Satisfaction Decisions",Journal of Marketing Research, 17, 4, 495-507. Oliver, R.L. (1997). Satisfaction: A Behavioral Perspective on the Customer, McGraw-Hill, Boston, MA.Pierre, C., Morwitz, V.G. and Reinartz, W.J. (2005), "Do intentions really predict behavior? Self-generated validity effects in survey research", Journal of Marketing, Vol. 69 No. 2 , pp.

$1-14$. Prendergast, G., Chuen, L.H. and Phau, I. (2002), "Understanding consumer demand for non-deceptive pirated brands", Marketing Intelligence \& Planning, Vol. 20 No. 7, pp. 405-16. Romaniuk, J. (2003), "Brand attributes - ,distribution outlets "e in the mind", Journal of Marketing Communications, Vol. 9 No. 2, June, pp. 73-92. Schiffman LG, Kanuk LL (2007). Reference Groups and Family Influences in Consumer Behaviour, 10th edition, Prentice Hall: London: 310-352.

Schlosser, A.E., White, T.B. and Lloyd, S.M. (2006), "Converting web site visitors into buyers: how web site investment increases consumer trusting beliefs and online purchase intentions", Journal of Marketing, Vol. 70, pp. 133-48. Staake, T., \& Fleisch, E. (2008). Countering counterfeit trade: Illicit market insights, best practice strategies, and management toolbox, ISBN: 3540769463, Berlin: Springer. Tom, G., Garibaldi, B., Zeng, Y. and Pilcher, J. (1998), "Consumer demand for counterfeit goods", Psychology \& Marketing, Vol. 15 No. 5, August, pp. 405-21.

Wang, 2004. Consumer decision-making styles on domestic and imported brand clothing. Euro. J. Marketing, 38(1-2): 239-252.

Yang, Y. T. (2009). A study of purchase intention behavior to consumers on innovation technology smart phone in technology acceptance model and theory of reason action. Unpublished master thesis, Nan Hua University, Taiwan. 


\section{Macrothink}

Zeithaml, V.A. (1988), "Consumer perceptions of price, quality and value: a means-end model and synthesis of evidence", Journal of Marketing, Vol. 52, pp. 2-22

Zeithaml, V.A. and Bitner, M.J. (2000), Services Marketing, McGraw-Hill, New York, NY.

Rizwan, M., Jamal, M. N., Abidin, Z., Zareen, K. G., Khan, A., Farhat, B. \& Khan, R. (2013) The determinants of Purchase Intentions towards Counterfeit Mobile Phones in Pakistan, Asian Journal of Empirical Research, 3(2), 220-236 